\title{
A Preliminary Study on the Application of Logistics Distribution Strategy in B2C E-commerce Enterprises
}

\author{
Chun Deng \\ Hainan Radio and Television University, N0.20 Haidian Erxi Road, Meilan District, Haikou, China \\ 847549719@qq.com
}

Keywords: B2C e-commerce; Logistics distribution; Third party logistics; Strategy

\begin{abstract}
The essence of logistics strategy application is to deliver goods for the customer timely and accurately, but the logistics distribution is a bottleneck in the development of commerce mode of B2C e-commerce environment. The development of electronic commerce has put forward new requirements to the $\mathrm{B} 2 \mathrm{C}$ logistics. In this paper, on the basis of analyzing some relatively successful $\mathrm{B} 2 \mathrm{C}$ enterprises about their distribution system features, we explore the strategies on logistics distribution for $\mathrm{B} 2 \mathrm{C}$ e-commerce.
\end{abstract}

\section{Introduction}

B2C is the abbreviation of Business-to-Customer, in Chinese, it is short for "Business to Customer ", and it can be called commercial retail. "Business to Customer" is one of the electronic commerce modes, namely, the direct-to-consumer marketing products and services. This kind of electronic commerce based on the network retail trade is to provide a new shopping environment for consumers through the Internet - online stores. Consumers go shopping online and pay online through the network. At present, B2C enterprise operation pattern in the market mainly has comprehensive shopping mall such as Taobao, department stores such as Dangdang and Joyo Amazon, vertical stores such as Mecoxlane and Redbaby, composite brand shop such as Giordano and Bell, light guide brand shop, the service online, engine type, etc. This article focuses on the two patterns, namely, department stores and vertical stores. As for the former pattern, we take Dangdang as an example, and the latter, we take Mecoxlane for example, so that to tell how different B2C enterprises adopt unique distribution strategies on the basis of the existing distribution mode.

\section{Analysis of Two Kinds of B2C E-commerce Business Model of Logistics Distribution Strategy}

Analysis of Dangdang Network about the Logistics Distribution Strategy. Dangdang is a well-known comprehensive online shopping mall, owned by domestic famous publishers, Kewen inc., America tigers fund, IDG group, Luxembourg Cambridge group, Asian venture capital fund (formerly known as Roftbank China venture fund) jointly established. Since November 1999, it was officially opened. At first, Dangdang sold books online and then started to sell various categories, including books, audio and video, beauty makeup, household, maternal and infant, clothes. As for logistics,Dangdang has achieved the goal that delivering its goods to 600 domestic cities within one day. In more than 1200 counties arrived the next day, cash on delivery (COD) covers 2700 counties covering the whole country.

Dangdang, in the United States time on December 8th, 2010 officially listed on the New York stock exchange, and became China's first fully online business, in the United States listed the B2C online mall.

The distribution system of Dangdang mainly focuses on outsource, and at the same time, it has self distribution center. At present, there are five logistics warehousing center of Dangdang in Beijing, Shanghai, Guangzhou, Chengdu, Wuhan, basically covering the country. Each distribution center sets up different product categories. Distribution center stock up quickly after receiving the order and distributed by express company or postal nationwide, Hong Kong, Macao and Taiwan and overseas areas by international shipping companies or EMS delivery. In all major cities, Dangdang will distribute business entrusted to the express company. Dangdang is in alliance with 
many urban express, the express company organization distribution team in his own city. In order to maintain a low cost, express companies in many cities choose bicycle as their transportation tool. Along with the increase in business to achieve economies of scale, express company will maintain the original bicycle delivery staff to increase delivery small teams, so instead of reducing distribution costs.

After completion of the inter-city transportation, Dangdang choose to cooperate with local third-party logistics companies, and do not build distribution around the team. Because the way of outsourcing is more flexible and cheaper, and easier to match each growth of region sales, At the same time by pulling the commodity suppliers and fostering a number of third party logistics companies to help them develop together. Outsourcing can make Dangdang focus on core business and expand international operations. At the same time, this supply chain management thought makes the service supply and demand form a strategic alliance, and on the basis of mutual benefit, it ensures the fast response of the enterprise to the customer demand.

Analysis of Mecoxlane Logistics Distribution Strategy. MecoxLane is also called the Wheat net, M18. MecoxLane lies in Shanghai, which is a famous online shopping site. Its predecessor was founded in January 8, 1996, Shanghai Mcglaughlin international mail order Co. Ltd. (MecoxLane). It is the first company in China to obtain government approval of the foreign-funded enterprises engaged in mail-order business, main business MecoxLane clothing, jewelry, household supplies, health supplies, pet supplies, such as a variety of goods, business covering the whole country. High quality of products, competitive prices, and outstanding customer service enable it to become the leader in direct and compound marketing industry. Mecoxlane has a complete logistics system supporting, including a variety of payment such as cash-on-delivery payment, which will allow you to enjoy safe and quick MecoxLane mail order service. In February 2008, Sequoia Capital China officially announced investment holding mail order giant McCaw, by acquiring the majority shares and became an absolute controlling party of McCaw, up to now, this is the biggest single investment of Sequoia Capital China and the first holding acquisition project. In October 2010, MecoxLane was being as "China B2C first shares" listed on Nasdaq, as catalogue mail-order plus offline sales plus online sales, through various channels to provide value to consumers of fast fashion products. In May 2014, district network Agel Ecommerce Ltd acquired $63.7 \%$ equity interest in Mcglaughlin, restructuring the company's business, peeling off bad assets, and guiding the business transformation. After the relocation, Mecoxlane focuses on meeting demands of the customers for their healthy and beautiful life and high quality standards. Through the strict selection of products, professional services, efficient communication, good interactive experience to become China's leading Internet era with social network marketing, leading healthy and beauty lifestyle of new enterprises.

In terms of logistics distribution, Mecoxlane deliver its goods from a large warehouse in Shanghai, outsourcing distribution to different third party logistics companies, and tend to choose the strongest local logistics company. Through the competition among them to control the logistics cost and service quality. Don't choose the self-built logistics, because it is only applicable in large and middle city, and 3-4 level cities need to outsourcing. After all, level in 2-3 cities orders are not large enough to cover the self-management logistics cost. Now, in the center of the Mecoxlane 10000 square meters of the delivery with the post office designated service can handle 10000 outbound the notice every day. Mecoxlane has established close cooperation with 60000 postal branches and 400 cities EMS across the country. In addition, Mecoxlane in some cities also provide 24 hours door-to-door delivery services.

Now, Mecoxlane is committed to the comprehensive upgrade of logistics system, with electronic gradually replace manual operation, at the same time, the shipping department will continue to expand networks and intensify the development of the secondary cities. In new logistics system, especially set up logistics distribution process query platform, so that consumers can more detailed understanding of the distribution process information, flexibility to adjust the time and place to receive the goods. The upgrades will be fully updated consumer's shopping experience, bring a win-win situation between the seller and the buyer. 


\section{Logistics Distribution Strategies Used in B2C Enterprise}

Combined with the above cases, the author makes the following discussion to the successful application of the $\mathrm{B} 2 \mathrm{C}$ enterprise to the logistics distribution strategy.

Set up Reasonable Regional Location. It is the first step to set up reasonable logistics distribution system in regional location. Setting up a very wide logistic network is unreasonable, because the customer of the geography position is very scattered, and the required delivery location is not concentrated. Therefore, we need to position the sales area and provide logistics commitment to the areas of the consumer population. Considering from economy, first of all, on the basis of Internet users are more concentrated in cities, it is easy to operate. For example, Dangdang on the basis of the growth in the volume of business in Beijing, Shanghai, Guangzhou, Chengdu, Wuhan, the establishment of storage center, from the point to the surface gradually strengthen their distribution capacity.

Setting up a Good Location. Not all the goods are suitable for the B2C e-commerce in this form, according to the different commodity consumption characteristics and flow characteristics of the specific analysis. Music, movies, games, pictures, books, computer software, and other logistics process can be done through the information transmission of goods are the most suitable e-commerce sales, because these goods can be complete reunification of business flow, good flow, information flow and cash flow. From the perspective of the rule of flow, require a commodity orientation to develop electronic commerce. Dangdang and Joyo Amazon started with specializing in books, Redbaby is an extended to five product line from specializing in maternal and infant products, Mecoxlane is only operating fashion clothes. Different commodity purchase and sales channels is not the same. The more variety the more complex supply channels and sales channels, the more difficult of the organization of logistics, which directly affect the logistics cost, thus affect the ability of the B2C enterprise for their distribution.

Distribution Network Settings. Although B2C enterprise is for the end customer, but its logistics system distribution terminal is not necessarily the customer. Such as the logistics system of 7.11 is in convenience stores for distribution terminal, express company is also trying to this kind of practice in reality. Indeed, convenience stores or distribution network as the object of distribution, can realize the centralized distribution to reduce distribution costs, also give customers a great deal of freedom. Of course, this model is covered with the premise of a comprehensive distribution network, but it is not necessary, the enterprise can invite chain stores, convenience stores, florists around the store paid to join the construction of a distribution system by agreement, this can yet be regarded as an good option.

To Optimize Distribution Channels. Determines the distribution area, but also for planning a delivery way. Because of reasonable distribution way both to save time and cost .Distribution route planning includes not only the distribution route arrangement, the choice between also includes distribution center. To determine the distribution way, it is necessary to apply on the knowledge of operational research. This is the B2C self-run logistics enterprises and logistics service provider will do their homework.

Cost and the Scale of Scientific Arrangement. B2C enterprise in setting up distribution outlets, transportation planning, vehicle loading, etc., will consider the cost of operability. E-commerce distribution of the characteristics of small batch and many frequency, is bound to cause the pressure of the logistics cost. So, in the distribution system to build, B2C enterprises should be carried out within the scope of their affordable cost distribution strategy implementation. The above example is presented.

To Build the Core Competitiveness of the Enterprise. To earn his place in the fierce market competition, enterprises must create their own core competitiveness, so that enterprises of every decision should be in the service of the center. For B2C enterprises, the construction of a distribution system directly affects the formation of competitive advantage. On the choice of distribution mode, Dangdang and Mecoxlane tend to outsourcing, Joyo Amazon and Redbaby tend to give priority to with self-run logistics, are out of their own strategic consideration. Regardless of 
what kind of pattern choice, B2C enterprises are at risk. The reason of chose one of them is can realize their differentiation.

The Construction of Logistics Information Platform. Information flow is infinite B2C enterprise common goal. This platform is $\mathrm{B} 2 \mathrm{C}$ enterprises, distribution customer in a timely manner the window of the exchange of information and business. Customers through the electronic commerce platform pass orders to shipping enterprise, the order information will be through the MIS is passed to the department for processing in time, so the distribution of MIS is the guarantee of realizing quick response to customers. After processed, orders are put into transport link, the goods in transit status, estimated time of arrival, consultation and complaints of distribution services and other information to convenient customer visit website. The platform can also develop CRM customer information resources, and intelligent decision-making functions. The successful application of the above examples of distribution strategy, there are the support of information technology.

\section{Conclusions}

The establishment of distribution system and strategy in an enterprise application need to consider the present policy environment, such as the coordination mechanism of the logistics industry, logistics revitalization plan, the market access system, leading trend of logistics enterprises and related logistics support policy, etc., If the specific implementation plan B2C companies can follow the policy form, and sometimes will receive a multiplier effect. In addition, we still need to build the perfect modern logistics distribution system. We need to think from the logistics operation system and logistics information system. The former is the operation of the logistics distribution system, while the latter is necessary for logistics distribution system to operate normally. Mutual coordination of the two helps to promote the development of the logistics distribution system.

\section{References}

[1] F.Fang: Transportation Management (Higher Education Publications, China 2015).

[2] S.X.Zhu: Logistics Transportation Management Affairs (Beijing Traffic University Publications, China 2009).

[3] C.S.Ji: E-commerce Logistics Applications (Electronic industry Publications, China 2009).

[4] M.N.Cai and J.S.Huang: The Chinese and Foreign Entrepreneurs, Vol.28 (2015) No.06, p.38-40.

[5] H.B. Yang: Modern Shopping Mall, Vol. 32 (2015) No.07, p.56-58.

[6] H.Du: Operators and Managers, Vol. 46 (2015) No.08, p.66-67.

[7] H.M.Lu: Manager' Journal, Vol. 23 (2016) No.01, p.36-37.

[8] Z.Chen: China Journal of Commerce, Vol. 52 (2016) No.03, p.18-20.

[9] Y.L.Pei, W. X. Xue and D. D. Li: Value Engineering, Vol. 25 (2016) No.04, p.42-44.

[10]L.J.Jiang: Journal of Commercial Economics, Vol. 42 (2015) No.36, p.32-34.

[11]Y.Hui: Logistics Engineering and Management, Vol. 45 (2016) No.02, p.38-39.

[12]Z.D.Zhu: Journal of Zhejiang Normal University (Social Sciences), Vol. 33 (2016) No.01, P.22-24.

[13] Y.Zhou: Business, Vol. 35 (2015) No.10, p.77-78.

[14]L.B.Tao: China Management Informationization, Vol. 51 (2015) No.22, p.55-56.

[15]M.Ling and J.Wan: Journal of Jiujiang Vocational and Technical College, Vol. 37 (2013) No.02, p.43-44. 
[16]C.Ying and M.F.Liu: E-Business Journal, Vol. 28 (2015) No.03, p.36-38. 